\title{
Keratectasia following laser in situ keratomileusis in a low-risk patient with benign joint hypermobility syndrome
}

\author{
Ectasia corneana após ceratomileuse a laser in situ em um paciente com baixo risco e apresentando \\ síndrome de hipermobilidade articular benigna
}

Gustavo Galperin ${ }^{1,2}$, Martin Berra $^{1,2}$, Alejandro Berra $^{2}$

\begin{abstract}
Here we present the case of a 27-year-old woman with benign joint hypermobility (BJHS) syndrome who developed keratectasia after laser in situ keratomileusis (LASIK) in both eyes. Both eyes had identical low Randleman risk factor scores. To our knowledge, this is the first report of such a complication in a patient with BJHS. It highlights our incomplete knowledge of the risk factors for keratectasia following LASIK and suggests that BJHS should be considered as a risk factor for keratectasia.
\end{abstract}

Keywords: Cornea/pathology; Corneal diseases/keratomileusis; Laser in situ/adverse effects; Joint instability; Case report

\begin{abstract}
RESUMO
Apresentamos um caso de estasia corneana em um paciente submetido à cirurgia refrativa a laser. Ceratomileuse a laser in situ (LASIK) foi realizada em ambos os olhos. Ambos os olhos apresentavam idênticos escores baixos na avaliação de fatores de risco de Randleman. Acreditamos que este é o primeiro caso desta complicação em um paciente com síndrome de hipermobilidade articular benigna relatado na literatura. Ele destaca o nosso conhecimento incompleto dos fatores de risco para ectasia corneana após LASIK e sugere que a síndrome de hipermobilidade articular benigna deve ser considerada um fator de risco para ectasia corneana.
\end{abstract}

Descritores: Córnea/patologia; Ceratomileuse assistida proexcimer laser in situ/efeitos adversos; Instabilidade articular; Relato de caso

\section{INTRODUCTION}

Keratectasia is a well-documented complication of laser in situ keratomileusis (LASIK) and photorefractive keratectomy (PRK), although it is more common after LASIK ${ }^{(1-4)}$. Potential risk factors include, but are not limited to, high attempted correction, thin residual corneal thickness, flap creation, irregular corneal topography, clinical keratoconus, and undiagnosed subclinical keratoconus ${ }^{(1)}$.

Benign joint hypermobility syndrome (BJHS) is a connective tissue disorder with hypermobility in which musculoskeletal symptoms occur in the absence of systemic rheumatological disease ${ }^{(5)}$. This syndrome is considered to be an inherited connective tissue disorder ${ }^{(6)}$. The primary clinical manifestations of BJHS are hypermobility and pain in multiple joints. It is different from other disorders that cause local joint hypermobility and generalized joint laxity, such as Marfan syndrome and Ehlers-Danlos syndrome (EDS).

Hypermobility that is not associated with systemic disease occurs in $4 \%-13 \%$ of the population ${ }^{(6)}$. The hypermobility diminishes as one ages, and it also appears to be related to sex and race ${ }^{6}$. Individuals of African, Asian, and Middle Eastern descent also have increased joint laxity ${ }^{(7-9)}$.

Here we describe the case of a 27-year-old woman with BJHS who keratectasia after LASIK (Figures 1, 2).

\section{CASE REPORT}

A 27-year-old woman with BJHS presented for a refractive surgery evaluation in August 2000. Her corrected distance visual acuity
(CDVA) was 20/20 with a manifest refraction of $-4.50-0.75 \times 180$ in the right eye and 20/20 with a manifest refraction of $-4.00-1.25 \times 180$ in the left eye. There was no significant history of ocular trauma or a family history of keratoconus, and she had no eye rubbing habit or other ocular issues. The patient had been wearing soft contact lenses for several years without incident.

She fulfilled the Beighton score ${ }^{(5)}$. Her medical history revealed arthralgia in two joints (right elbow and right wrist) for more than 6 months, two episodes of shoulder dislocation, a marfanoid habitus, myopia, and mitral valve prolapse.

At the time of consultation, her refraction had been stable for more than 3 years, and both topography and pachymetry findings appeared normal. Topography revealed symmetric bow-tie patterns in both eyes. Central ultrasonic pachymetry revealed a corneal thickness of $515 \mu \mathrm{m}$ and $513 \mu \mathrm{m}$ in the right and left eyes, respectively. Central keratometry revealed a corneal surface curvature of 42.99/42.24 diopters (D) in the right eye and 42.77/42.18 D in the left eye, representing a topographical cylinder $(0.75$ and 0.59 , respectively; Figures 3 A and 3 B). According to the Randleman customized ectasia risk score, each eye represented a low risk for the development of excimer keratectasia.

Uneventful LASIK was performed in November 2000 on both eyes, with a 1-week interval between surgeries. The Automated Corneal Shaper microkeratome (Bausch \& Lomb) with a 160- $\mu \mathrm{m}$ plate and a Meditec MEL-60 excimer laser was used. In both eyes, the optic ablation zone was $6 \mathrm{~mm}$, and the estimated ablation depth was $43 \mu \mathrm{m}$. The intended correction was the manifest refraction in both eyes. 
Three months after surgery, the uncorrected distance visual acuity (UDVA) was 20/20 in the right eye and 20/20 in the left. Biomicroscopy was clear, and the patient was discharged from the clinic. In May 2006, she returned, reporting that the visual acuity in the right eye had deteriorated over the past 6 months; she reported no problems with the left eye. The UDVA was 20/200 in the right eye and 20/20 in the left eye. The CDVA was 20/25, with a refraction of $-4.00 \times 70^{\circ}$ in the right eye. The intraocular pressure remained normal before and after surgery. With the OCT Visante, the LASIK interface was not visible. The Reichert Ocular Response Analyzer (ORA) showed low values for cor-

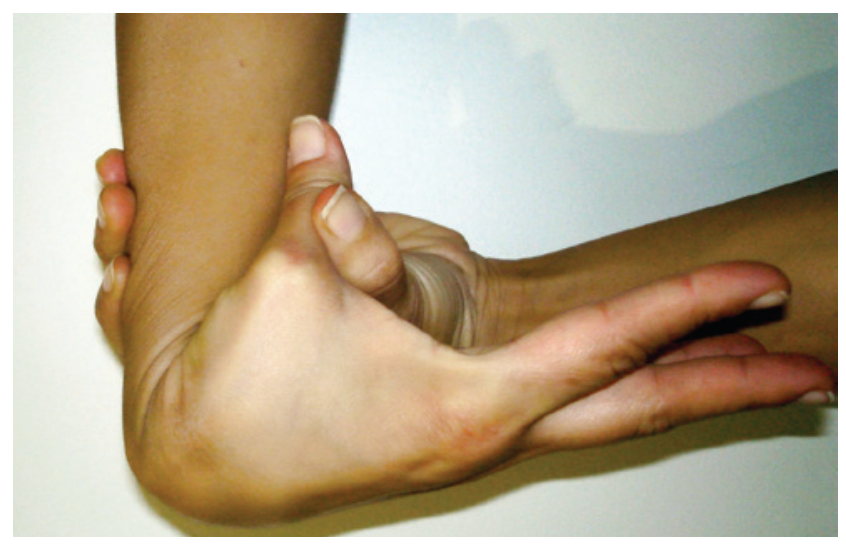

Figure 1. Apposition of the thumb to the flexor aspect of the forearm. neal hysteresis $(\mathrm{CH}$; right eye, 7.4 ; left eye, 8.5$)$ and corneal resistance factor (CRF; right eye, 6.3; left eye, 6.9). Topography (Orbscan, Bausch \& Lomb) of the right eye showed an irregular pattern, suggestive of corneal ectasia (Figure 3C). Pachymetry revealed a thickness of $402 \mu \mathrm{m}$ at the thinnest point. The posterior float was $125 \mu \mathrm{m}$.

Topography (Orbscan, Bausch \& Lomb) of the left eye appeared normal. Pachymetry revealed a thickness of $408 \mu \mathrm{m}$ at the thinnest point. The posterior float was $42 \mu \mathrm{m}$ (Figure $3 \mathrm{D}$ ).

Because the surgeon believed that it was important to minimize the possible progression of keratectasia while the patient was away, corneal collagen cross-linking with riboflavin and ultraviolet A (IROC, Zurich, Switzerland) irradiation was performed in 2007. Both eyes remained stable during 5 years of follow-up.

\section{DISCUSSION}

Corneal ectasia is a serious complication of laser refractive surgery. Progressive distortion of the cornea can lead to a significant de-

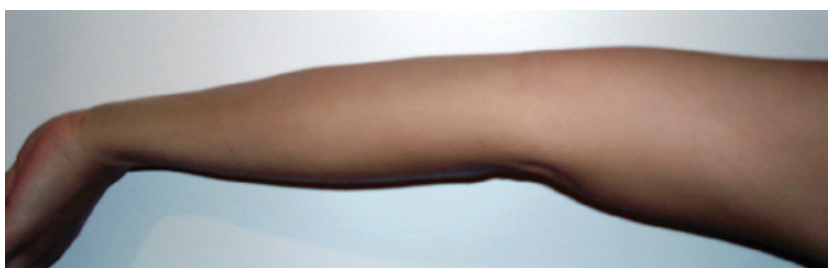

Figure 2. Hyperextension of the elbow beyond 90 degrees (neutral).
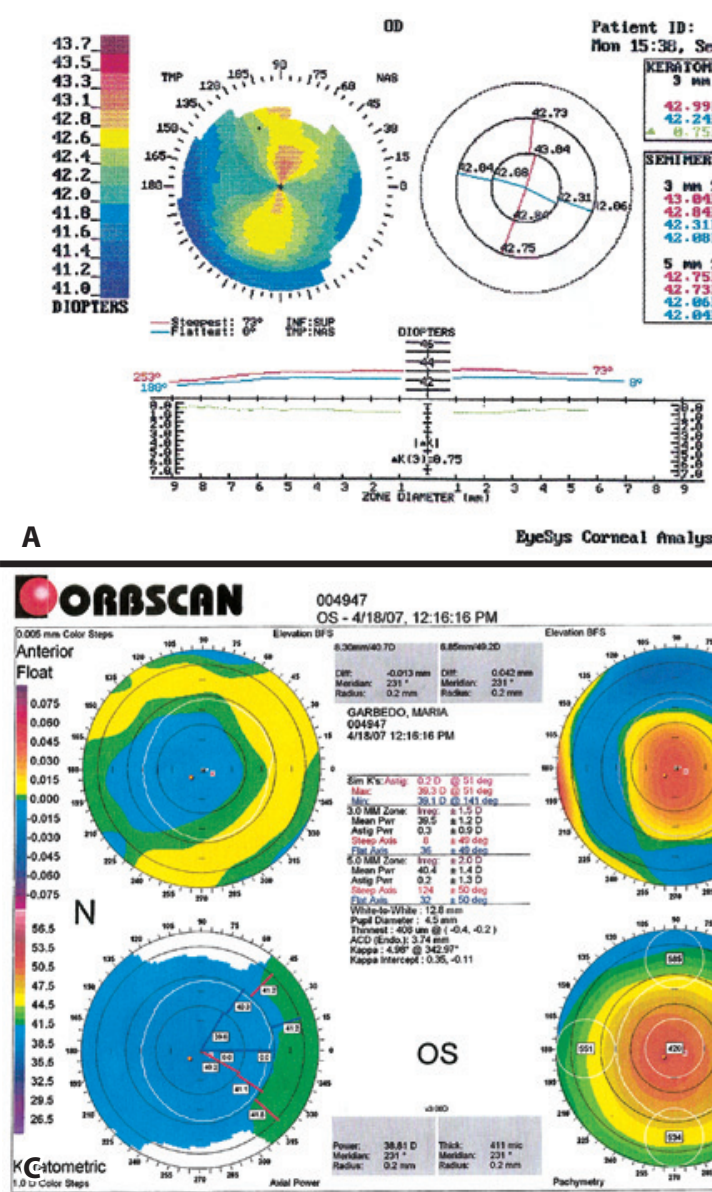

ByeSys Corneal Amalysis Systen

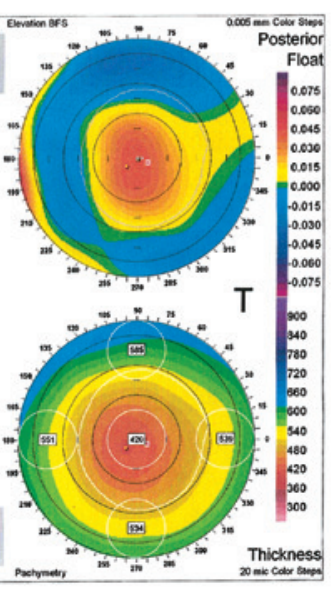

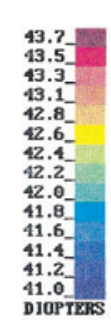
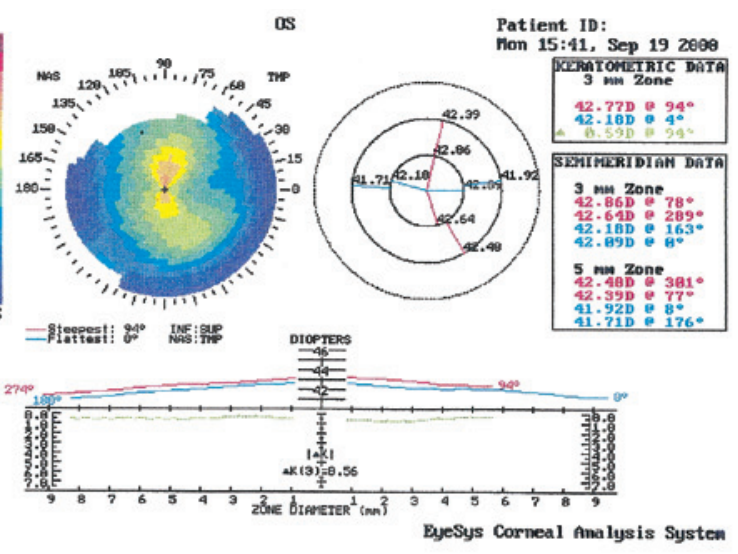

B

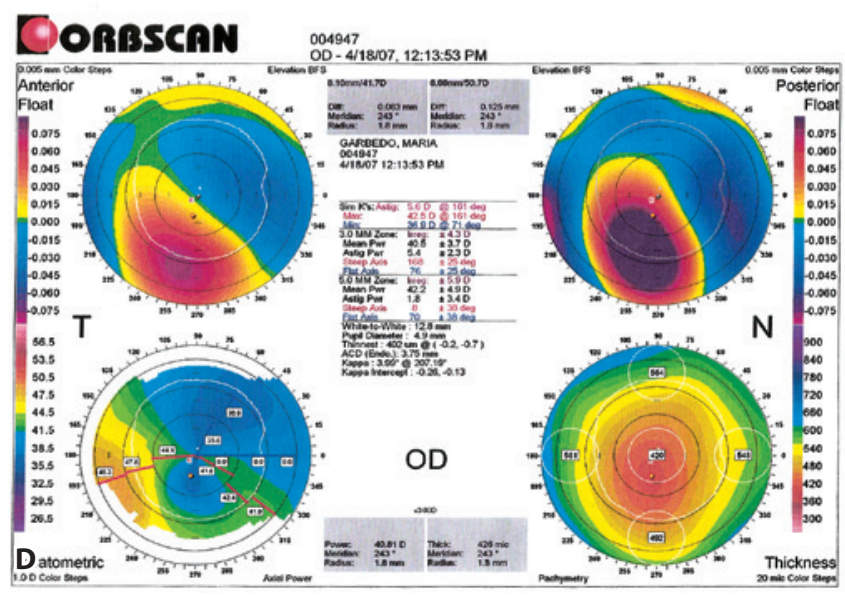

Figure 3. A) Preoperative right topography. B) Preoperative left topography. C) Postoperative right topography. D) Postoperative left topography. 
crease in CDVA and may ultimately require transplantation for visual rehabilitation. Although several risk factors have been well outlined, the pathogenesis of the condition is not clearly understood ${ }^{(3)}$. Various authors have attributed age, preoperative corneal pachymetry, residual stromal bed thickness, high preoperative correction, number of enhancements, flap creation, the presence of subclinical corneal disease, or high posterior float on topography to be related to the onset or progression of ectasia ${ }^{(1-3)}$. Our patient's preoperative and intraoperative assessments with no known risk factors suggest that the patient was at a low risk of developing ectasia. Before surgery, CDVA was 20/20 in both eyes. Her refraction was not high and had been stable for several years. Preoperative corneal topography and pachymetry findings appeared normal in both eyes.

Because of the retrospective nature of the case, the preoperative topography maps were not available for further review, and no further comment on the same is possible.

BJHS may be a sign of biomechanical weakness and a possible risk factor for keratectasia.

In conclusion, we described the first case, to the best of our knowledge, of keratectasia after LASIK in both eyes in a patient with BJHS. The right eye developed late-onset ectasia despite the relative absence of presurgical risk factors. We suggest that screening for BJHS as a possible risk factor will limit the incidence of ectasia in these patients and support the decision to proceed with an alternative to LASIK surgery. Alternative surgical options, including surface ablation and phakic intraocular lenses, should be considered patients with BJHS.

\section{REFERENCES}

1. Randleman JB, Russell B, Ward MA, Thompson KP, Stulting RD. Risk factors and prognosis for corneal ectasia after LASIK. Ophthalmology. 2003;110(2):267-75.

2. Comaish IF, Lawless MA. Progressive post-LASIK keratectasia; biomechanical instability or chronic disease process? J Cataract Refract Surg. 2002;28(12):2206-13.

3. Chan CC, Hodge C, Sutton G. External analysis of the Randleman Ectasia Risk Factor Score System: a review of 36 cases of post LASIK ectasia. Clin Exp Ophthalmol. 2010; 38(4):335-40

4. Randleman JB, Caster Al, Banning CS, Stulting RD. Corneal ectasia after photorefractive keratectomy. J Cataract Refract Surg. 2006;32(8):1395-8.

5. Grahame R. The revised (Brighton 1998) criteria for the diagnosis of benign joint hypermobility syndrome (BJHS). J Rheumatol. 2000;27(7):1777-9.

6. Biro F, Gewanter HL, Baum J. The hypermobility syndrome. Pediatrics. 1983;72(5):701-6.

7. Engelbert R, Uiterwaal C, Van de Putte E, Helders P, Sakkers R, Van Tintelen P, et al. Pediatric generalized joint hypomobility and musculoskeletal complaints: a new entity? Clinical, biochemical, and osseal characteristics. Pediatrics. 2004;113(4):714-9.

8. Everman DB, Robin NH. Hypermobility syndrome. Pediatr Rev. 1998;19(4):111-7.

9. Finsterbush A, Pogrund H. The hypermobility syndrome. Clin Orthop Relat Res. 1982; 168:124-7.

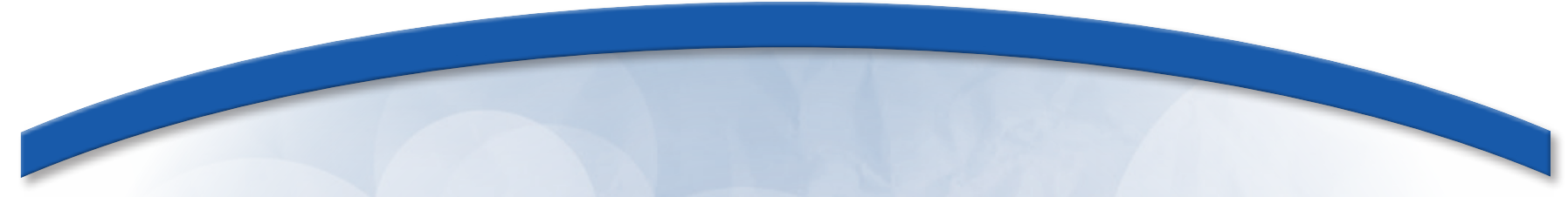

\title{
XVII Congresso Internacional da Sociedade Brasileira de Oftalmologia
}

\author{
23 a 26 de julho de 2014 \\ Hotel Windsor Barra \\ Rio de Janeiro - RJ
}

Informações:

Tel.: (21) 2554-7000 (Sandra Regina)

E-mail:contato@congressosbo.com.br

Site: www.congressosbo.com.br

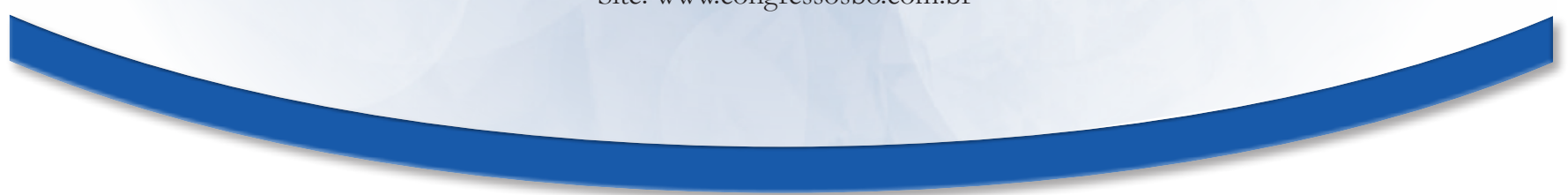

